\title{
Trade unions in a constrained environment: workers' voices from a new industrial zone in India
}

\author{
Anita Hammer
}

\begin{abstract}
Challenges to unions worldwide are often framed in a strategic tension between enterprise unionism on one hand, and mobilisation for unions' continued relevance under neoliberal global capitalism on the other. However, research in a New Industrial Zone (NIZ) in India reveals a complex picture: a variety of unions across firms that are not always explained by existing definitions and models. Alongside political and enterprise unions, a third dimension emerges out of new forms of grassroots community links rooted in the living areas of workers. This paper argues for a socio-historical institutional analysis of union-worker-firm-state relations under the new political economy of a NIZ, with a focus on workers' experiences and living areas, in order to explain the varied structures and strategies of unions.
\end{abstract}

\section{INTRODUCTION}

The Indian experience adds a further layer of empirical richness and complexity to the debate on the future and nature of trade unionism (see Edwards, 1994; Fairbrother, 2000; Kelly, 1998; Tilly, 1978). The interaction of the indigenous political economy with global capitalism in newly industrialising areas - New Industrial Zones (NIZ) has far-reaching implications for both workers and their unions. Based on qualitative research in a NIZ, this paper reveals the contested and uneven experiences of workers and unions. There is a dominant trend towards enterprise unionism, albeit accompanied by experience sharing and mobilisation outside the workplace in the neighbourhoods of workers. However, in the Indian context, enterprise unions can be narrow company unions controlled by management, whereas at the other end of the spectrum, political unions often ignore workplace issues and become transmission belts for political parties. Thus, the key debate here has been whether or not such unions should be mobilised and affiliated into wider political federations.

What is overlooked in this longstanding controversy is another emerging model of unionism: new forms of grassroots community links grounded in the living areas of workers, and it is this model that constitutes the focus of this paper. It shows how different forms of Indian unionism within a NIZ resulted from the interaction of the

$\square$ Anita Hammer is $\bullet$. Correspondence should be addressed to Anita Hammer, ••; e-mail: ahammer@, dmu.ac.uk

(C) 2010 The Author(s)

Journal compilation (C) 2010 Blackwell Publishing Ltd, 9600 Garsington Road, Oxford OX4 2DQ, UK and 350 Main St., Malden, MA 02148, USA. 
broader historical-institutional context, global capitalism, as well as particular local labour control regimes. They are analysed here within a socio-historical institutional framework (Ackers, 2005). It is argued that capturing the local dynamics of work and unionism necessitates an integrated analysis of the workplace and the living spaces of workers. Such an approach helps explain aspects of both union structures and strategies of worker mobilisation in the region. Importantly, this methodological focus gives a voice to workers, often overlooked in academic works, at the same time offering the only feasible design to research NIZs with their restricted access to firms.

\section{HETEROGENEITY, WORKERS' VOICES AND UNIONISM: ISSUES IN INDIAN INDUSTRIAL RELATIONS}

A review of Indian industrial relations highlights three aspects pertinent to this study. First, Indian labour reality is complex, where work and living spaces of workers, as well as caste identities and political considerations are interlinked and influence workers' worldview and strategies. Second, the role of the state and the persistent institutional heterogeneity within the national context has an impact on the nature of unionism. Third, the above factors pose particular challenges for forms of unionism and worker mobilisation in India, especially in their interaction with global capitalism. The analytical framework of this paper accommodates both heterogeneity within national contexts, as well as workers' experiences and agency across their specific working and living spaces in a NIZ. In doing so, it presents alternative paths of mobilisation adopted by workers and unions.

For labour in India, class identity has historically intersected with caste identities. Persistent links between the workplace and the living spaces of workers impact upon social interactions, mobilisation and political networking. Industrial sociologists and labour historians have successfully conceptualised work and living spaces as integrated without diverting attention away from the material domain (Gooptu, 2001; Joshi, 2003; Parry et al., 1999; Ramaswamy, 1997 for India; Ackers, 2002 for Britain). This has significant implications for the methodological approach to researching work in general, and the nature and strategies of unionism in particular.

Further, contemporary unionism cannot be separated from the emergence of the modern Indian state. The historical association of unions with the freedom struggle, as well as the post-independence links between the developmental state, political parties and labour resulted in highly politicised and fragmented forms of unionism. As a consequence, Indian unionism displays inter-regional and inter-city heterogeneity originating from a plethora of different (federal and provincial) laws, as well as political coalitions. These resulting models of unionism range from politically affiliated left-leaning trade unions in West Bengal, independent and unaffiliated enterprise unions in Maharashtra that are referred to as 'Indian version of business trade unionism' (Ramaswamy, 1988: 17), 'footpath unionism' and social-movement unions of unorganised workers (Self Employed Women's Association, SEWA) in Gujarat, and radical and militant trade unions in the industrially and socially backward states of Andhra Pradesh and Bihar. As the neoliberal state progressively eschews direct involvement in industrial relations, the emerging political cleavages within state governments, political parties and central union federations all add further complexity to the post-independence model of unionism (Bhattacharjee, 2001; Harriss-White and Gooptu, 2001; Kuruvilla and Erickson, 2002; Kuruvilla et al., 2002; Ramaswamy, 1997; Venkata Ratnam, 2001). 
In addition to such realignments in India, the interaction of the indigenous political economy with global capitalism, particularly pronounced in NIZs, which emerged since the 1990s, adds a further dimension. Here, increased flexibility and control over labour and unions is marketed as a major attraction to foreign investors, and (provincial) state governments compete by diluting labour laws (Kuruvilla et al., 2002). It is not uncommon for labour laws to be circumvented via executive regulations. This assists those organisations eager to allow enterprise unions at the expense of crossindustry or politically driven forms of labour representation (for examples, see Trivedi, 2006; 2007; Venkata Ratnam, 1998).

In this cold climate, challenges to unions on representation, membership, revitalisation, as well as relations between central union federations, political parties and state authorities, have become sharper. Traditional political unions are criticised for their focus on rent-seeking and the representation of elite and sectional interests. Instead of providing a base for popular participation, they have become transmission belts for political parties, fostering sectarian divisions to the detriment of workplace issues. An alternative strategy is for unions to withdraw from the formal political arena, privileging workplace concerns through enterprise unionism. Politically affiliated unions, however, perceive the withdrawal from the political arena as problematic, since enterprise unionism may generate parochial company unions, controlled by management, with a strictly delineated sphere of influence (Bhattacharjee, 2001; Harriss-White and Gooptu, 2001; Mamkoottam, 1982; Ramaswamy, 1997; Sanyal, 1991).

In this context, there is an increasing emphasis on establishing new linkages with civil society groups and a move towards social movements for wider and inclusive representation as advocated in the mobilisation literature (Kelly, 1998; Tilly, 1978). Significantly, 'new' forms of organisation, such as SEWA, which views itself as a social movement and a trade union, have been successful in addressing the societal as well as the individual aspects of social exclusion of the poor. Such a focus on a specific constituency - poor women in this case - and specific issues, separate from traditional trade unions, have been considered successful (for details on SEWA, see Rose, 1992; Sanyal, 1991; 1994). Trade unionists, however, criticise 'new' forms of mobilisation for their limited geographical reach and exclusivist approach to organising. The implicit localism carries the danger of reflecting prevalent social and cultural prejudices, thereby reproducing deep conflicts of interest and asymmetric power relations. They could fall prey to the mobilisation of particular interests or ideologies and might end up resembling more the trade unions they criticise (Hyman, 2004). As has been argued with regard to transition economies, the same social movement that helps mobilise labour against a particular social set-up can undermine labour's interests and a union's basic workplace mission when the social movement succeeds (Ost, 2002 for Eastern Europe; Von Holdt, 2002 for South Africa). According to a central federation Secretary:

These new kinds of trade unions or movements are not always representative . . If the trade unions do not represent workers then who does? I don't consider them [social movement unions like SEWA] a trade union although they call themselves one. The divisions between men and women workers, between organised and unorganised labour are artificial and created by vested interests . . . they do not want labour to unite ... these are divisions created by the government and international interests.

To sum up, there are important interactions of class-caste-politics in the evolution of Indian labour and tensions between workplace and political mobilisation in its unionism. Models of unionism and worker mobilisation have different meanings on 
the ground. Links with the state through political unions have historical antecedents and influence workers' attitudes, even as they get redefined in a post-colonial context and under neoliberal global pressures. Political unionism may become exclusivist, divisive and at times a transmission belt for political parties, while enterprise unions, which can be narrow company unions controlled by management, may be more responsive to workers' issues. This necessitates a deeper understanding of unions, their structure and strategies, as well as their place-specific character, which emerges from the interaction of global capitalism with workers, unions and the state at multiple levels. The integrated analysis of workers' work and living spaces in this paper allows us to understand and account for workers' capacities to formulate alternative strategies across their different social spaces. Such an approach is particularly important in researching the constrained environment of a NIZ.

\section{LIVING WITH WORKERS IN A NIZ}

The research was conducted in the NIZ of Noida and Greater Noida, with a population of about 1.2 million people in a space of $1,501 \mathrm{~km}^{2}$, in the north Indian state of Uttar Pradesh (UP). The nature of industrialisation in Noida and Greater Noida is relatively new and driven by the dynamics of the NIZ format: high levels of foreign direct investment in manufacturing, neoliberal state policies and a large pool of workers. It is a rapidly growing urban industrial centre with a significant influx of migrant workers, which exists alongside a predominantly agrarian population. Rapid development accompanies vast inequalities, and widening participation in democratic processes is paralleled by increasing polarisation along regional, caste and religious lines. The state has eschewed its protective welfare role and moulded its traditional clientilist features in a neoliberal context. Although social movements on agrarian issues and social reform, as well as caste-based movements have existed in the region, there is little history of trade union organisation.

The designation of the region as NIZ came with extensive deregulation of labour law, aiming to 'facilitate' the flow of foreign investment to the region. For example, all industrial units established in NIZs are exempted from general labour laws for 6 months (which can be extended further by the Development Commissioner). Also, the Development Commissioner of Noida NIZ is authorised to exercise all powers of a Labour Commissioner. Furthermore, the Contract Labour Act 1970 was streamlined and simplified, and powers were delegated to the Development Commissioners in NIZs, who act as Registration and Licensing Officers. Measures such as these played a crucial role in creating a cheap and malleable workforce and constraining unionism.

The focus of the research was on how workers' experiences are transformed into collective strategies across working and living spaces and its implications for trade unions. The research design was inspired by Burawoy's (2000) 'global ethnography' for grounding globalisation, and Hassard et al. (2007) argument for grounding the analysis of multinationals in a 'community-based ethnography'. Beyond epistemological considerations, this design offers the only feasible way to research firms in NIZs, as access is restricted and workplace fear is palpable. Constraints at the workplace meant workers could only talk freely and without fear of repercussions in their own environments. This was brought home poignantly when the author suggested to a group of workers about a visit to their workplace to gather data: 
[A general quiet fell. After a while, my host spoke up hesitantly] You are most welcome, of course . . . but you realise how work is organised. We are not allowed to talk. And you will be accompanied by management people. They will not let us speak. We would not like to speak in front of them. You understand, don't you, that this is better.

The antagonism between management and labour dictated that interviews were conducted largely in the living spaces of workers. Indeed, the five months of field work involved the researcher 'living' with the workers from morning till evening. Importantly, it facilitated the capturing of the cross-linkages that exist between actors and institutions, and brought home the way in which the reality of work-specific concerns was reproduced, expressed, opposed and negotiated in living spaces - a context where links between work and community, as well as between workers and the state, are immediate and crucial.

For the research, a cross-section of workers was interviewed based on the nature of employment contract (permanent and temporary), firm (domestic and multinational), place of origin (local and migrant), age (younger and mature), skill and whether they were union officials. The firms studied were manufacturing subsidiaries, joint ventures and local firms that were mostly set up at the creation of the NIZ. Firms were selected to represent ownership structures, size, technology and union status, as well as the industries operating in the area. Table 1 provides a profile of firms and the nature of unionism.

Equally, living areas correspond to a cross section of residential areas. Out of the six residential areas studied, with the exception of the two authorised company colonies, the other four had a mix of workers from different firms living in close proximity. Their characteristics are outlined in Table 2.

Workers were identified through a 'snowballing' technique. The methods comprised interviews and focus groups with workers from eight firms across five industries. In total, 80 semi-structured interviews (10 for each of the bigger firms and 6-8 for the smaller Indian firms) and eight focus groups within and across firms (ranging from 8-15 members) were conducted over a period of five months in structured discussions ranging from two to six hours. This combination of methods was crucial in bringing out the similarities and differences of experiences and responses. In addition, key company and government documents were analysed, and interviews were conducted with employer representatives from chambers of commerce, officials of central trade union federations and labour officers from the ministry of labour.

\section{UNIONISM IN A NIZ: WORKERS' VOICES}

The dynamics in the NIZ displayed tension, both in the strategies of unions and in workers' attitudes to unions. First, there was a forced and pragmatic focus on workplace issues in a narrow form of enterprise unionism. Constraints in affiliating to political unionism were accompanied by unmet expectations from the state to act as a support of last resort; in fact, the state extended support to employers in containing unionism. This largely enterprise-centred unionism in the absence of strong workplace structures is discussed in the next subsection. Second, a workplace focus of unions was at the same time characterised by attempts to build wider affiliations. Faced with severe constraints on organising and managerial power at the workplace, shared dissatisfaction of workers was expressed in their living areas, which sometimes served as a basis to form emergent collective solidarities. This extended the spatial reach of unions into the living areas of workers and the strategy of mobilising in these 


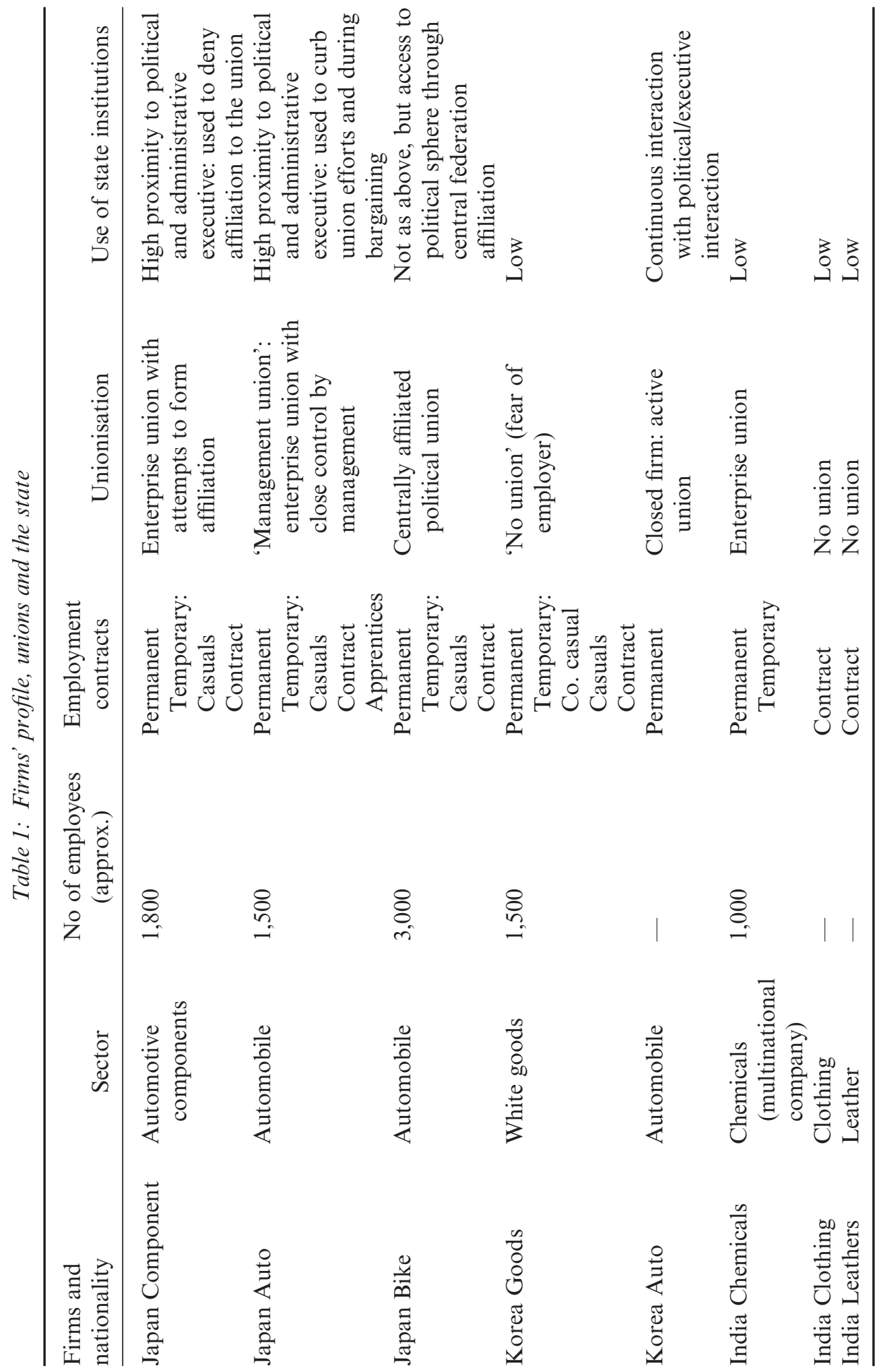

(C) 2010 The Author(s)

Journal compilation (C) Blackwell Publishing Ltd. 2010 


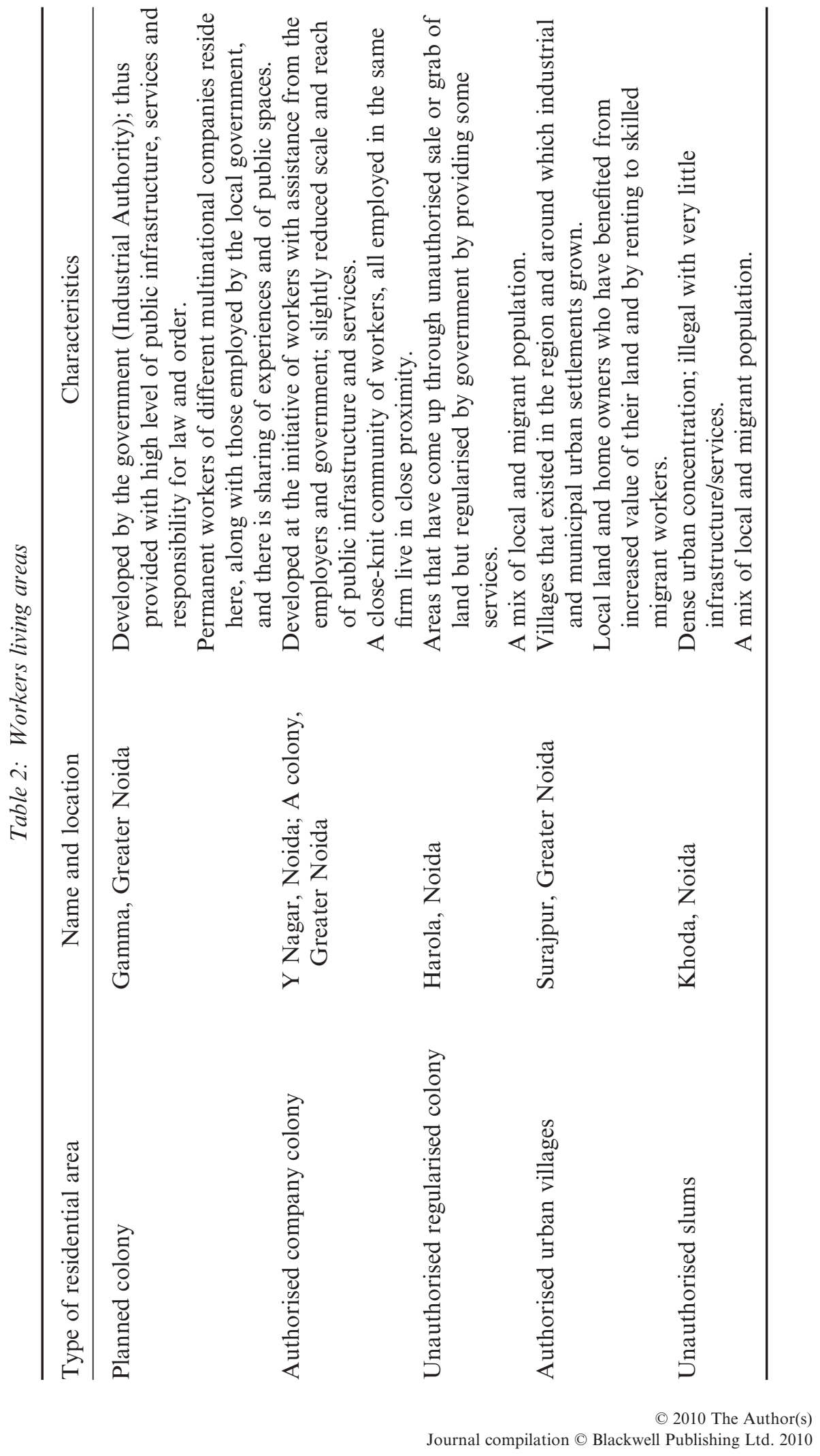


areas. This is elaborated in the second subsection. The implications of these developments for unionism are discussed in the third subsection.

\section{Workplace and the state: towards enterprise unionism}

There was a perceptible trend towards enterprise unionism in the NIZ. Of the eight firms studied, five had some form of union and four of these had enterprise unions (Japan Component, Japan Auto, India Chemicals, and Korea Auto. The latter was unique in that it was an enterprise union while the firm was operational, but sustained a campaign for salaries, compensation and alternative jobs $v i s-\grave{a}$-vis the political and administrative executive post-closure). Significantly, the unions represented varied shades of unionism that resulted from different configurations of union-firm-state relations in each. While home country effects, management resistance to trade union organisation, and employer mobilisation of state interventions influenced unionism in the Japanese firms, disillusionment with the historical role of political unions and a choice by workers and unions leaders determined the nature of the union in the Indian multinational.

In the two Japanese firms, Japan Component (an auto component firm) and Japan Auto (an automobile firm), employer practices enforced strictly controlled work regimes and curbs on wider affiliation by unions. In keeping with the country-oforigin effect, enterprise unions were the norm. Compulsion rather than choice determined the nature of unionism. In Japan Auto, workers' attempts to form their own union were curtailed by management. According to workers, management used its proximity to the political executive and Labour Commissioner to deny recognition of the union. Workers attempting to form a union were dismissed. In its place, a union was established with the 'blessings' of the management that was dismissed by the workers as 'Management Union':

\footnotetext{
This union is management's union . . . what use is that? It was just their way round things after the dirt they raised. They speak the language of the management.

Have you ever heard of police in the room when bargaining is taking place . . if that is not to scare us, what is? Who would like to become union representative when this goes on? Employers and officials of the state together intimidate and victimise us.

You think of a union and you are out! Not only that, they will victimise you. The personnel here have such connections with the police and officials. That is why they are employed . . that is why they were successful with the union.
}

Attempts to forge alliances with central trade union federations by the union were disallowed in both firms. In Japan Component, the Union President had links with one of the central federations, but his efforts to form a political affiliation were resisted successfully by management. While employers were tolerant of an enterprise union, they resisted any wider alliances. Additional assistance was provided by the state (provincial/local), which intervened selectively at the workplace largely on behalf of employers. Japan Auto showed a greater reliance on the institutions of the state in controlling workers and unions.

Attempts to unionise were made from 2001-3 with the help of a federation. Matters reached the Office of the Labour Commissioner but the union could not be registered. It is all because of the General Manager, he is close to the Chief Minister. A lot of money exchanged hands at the Labour Commissioner level. It was all proved when those active in the unionising attempt were suspended and false judicial/police cases were instituted against them . . . how dirty can you get? And it showed the reality of these people [Focus group of workers of Japan Auto]. 
In the context of severe restrictions on organising and other unfair practices by employers, such as the indiscriminate firing of workers and a move towards subcontracting, which provoked fear and insecurity, workers constantly alluded to the role the state (federal) played in restricting union organisation through legal provisions and policies.

What use is the right (to form unions)? It is our own government who is supporting all that is going on. Don't they know what is going on? [Mixed focus group of workers]

The claim that the employers were powerful partly because of state support at all levels was a common complaint:

It would be nice if the government could exercise more control over the working conditions, especially the number of hours and the kind of salary paid and over contractors and employers ... But how can this happen when all the state functionaries are corrupt and in the pocket of employers... Also how much can the government do when unemployment is so high and trained people are willing to work for less and less? [Company causal, Japan Component]

It was widely believed that political patronage was extended in return for the award of contracts, as well as jobs for the favoured few. The evident employer-state compact disheartened workers, such as those in Japan Component. While workers were supportive of their evidently active Union President, they often articulated the futility of expecting any state support.

Don't know how things will go? Right now employers seem to have all the control. They are powerful people who have all the connections (with the state). Our President is good and unions try but there does not appear much scope for state support.

The expectations of the union leadership regarding the role of the state (federal) also influenced the nature of unionism. In the third case, India Chemicals, an older and established Indian chemical MNC, labour had developed a different strategic orientation based on the historical specificity of the nature of Indian unionism.

What state? We have no expectations nor is it effective. Ultimate solutions come through bilateral talks. Labour Officers and Commissioners are corrupt and all are in the pockets of the employers. The Courts speak their language as well [Union worker, India Chemicals].

The union had broken its alliance with a central political federation because of the workers' dissatisfaction with it and switched from a politically affiliated union to an enterprise union.

We used to have an outside union but they never understood what mattered to us. They would involve us in outside issues. They were always motivated by political interests of their own and would force us to go on strike. Then they would strike a deal with the employer or whoever on the outside while we would be left on our own. No interest in our suffering! These outside unions don't know anything about our lives, how can they represent us? [Focus group of workers]

The President was vocal in his criticism of the nature of the earlier union.

We formed our own employees' union in 1993. There was an incident when the CITU union (to which they were affiliated then) had pushed us into a strike and then withdrawn after a deal. We changed the union then ... and we did it ourselves. The workers formed an enterprise union. Now the union and its leaders work for their own workers. We bargain on all issues, wage and welfare related [Union President].

Thus, there is often a difficult relationship between enterprise unionism and political affiliation in that unions are either too weak to affiliate or too weak to accommodate the contradictions that might emerge between broader political strategies and their own interests at enterprise level. Workers and unions were responding to constraints 
at the workplace-increasing managerial control and NIZ-specific restrictive state policies - by focusing on the workplace either by compulsion or by choice/ pragmatism rather than as part of a political-industrial strategy. However, such developments were being negotiated and ridden with contradictions. Though critical of state support to employers, workers were happy to use the same mechanisms to gain employment or obtain contracts. At one level, they articulated that workplace unionism might serve their interests better (India Chemicals, Japan Component). At another, a majority of workers interviewed (India Chemicals and Korea Goods being the exception) hoped that the state and political unionism together might help counter the injustices at the workplace (Japan Bike and Korea Auto). The tenor of discussions was anti-employer but not anti-state.

The state can be very effective if it treats us workers and the employers in an even handed fashion. The government is our last hope. The managers and the Korea Auto owners have run away . . . they cannot be caught. It is the local, provincial and central level officials and politicians who are our only hope [Korea Auto worker].

Ultimately it has to be the government that has to do something. We have all tried inside the workplace ... if someone speaks; he is a marked man and will be pulled up later on . . . [So] nobody speaks. Yes, the government has made the policies . . . but it has also said you cannot keep more than $20 \%$ of casuals as compared to the permanents in the workforce [Union functionary, Japan Auto].

In the face of these constraints at the workplace - employer mobilisation of state interventions, as well as labour's weakening political influence vis-à-vis the state (all levels) - it is strategically and politically significant that the very evident workplace focus of workers and unions was accompanied by experience sharing and mobilising in the living areas.

\section{Alternative paths beyond the workplace: cross-firm links, experience sharing and neighbourhood mobilisation}

Alternative strategies have emerged in the area of study, which widen the focus from the enterprise level and often link working and living spaces in building organising strength and expressing workplace-based issues. The area of study has developed as a contained regional unit with a concentration of workers in extant residential areas close to their places of work on account of the developing nature of the industrial and other infrastructure. In most of the six residential areas studied (Table 2), a mix of workers from different firms lived in close proximity forging social relations and sharing spaces. As a result, significant cross-firm and cross-category links emerged and existed among workers in their living areas, which contributed to their sense of 'sameness'. This, along with the absence of avenues of expression at the workplace, led union leaders to mobilise or workers to liaise with them in their living spaces rather than in workplaces, thus widening the spatial coverage of unions and shaping their strategies of organising.

Ties of family, caste, place of origin and/or communal activities, religious congregation or cricket teams, served as a basis of solidarity across firms and different categories of workers:

We are close to each other here. We face the same problems at work. If we do not understand each other, who will . . . it is part of being human [Group of workers at a religious gathering].

My brother-in-law is a temporary worker. How can I not understand his problems? [Permanent worker, Japan Bike] 
Such close proximity of existence and multiple ties facilitated continuous experience sharing among workers, with a clear awareness of policies and practices of firms other than their own.

\begin{abstract}
The kind of workload put on the Korea Auto workers is dangerous. You can't blame them if they don't speak up; they have their families to think of. They are all working for the money but it is harmful because there can be accidents because the workers are tired ... they fall ill. The firm will throw them out ... it is just exploiting their necessity! [Mature workers of Japan Component and Japan Bike]

Have you heard of Japan Auto's skilled apprentices? The firm uses them to get the work done without paying full salary. They were brought here on false promises, made to give up permanent jobs! [Workers
\end{abstract} of other multinational firms]

Japan Bike has good working conditions. They have even tried to do things for the contract workers. That is what we want [Mixed focus group].

Such sharing of experiences displayed a keener focus because of a combination of job insecurity, unfair working practices and fear of intimidation.

There aren't many jobs around and people are willing to work for less and less. Most of us put up with misconduct [by employers] and the employers get away with it because the government supports it [Mixed focus group].

In sum, the expression denied to the workers at the workplace found an outlet in their living areas as experiences were shared, creating a sense of 'us and them' among workers. This often resulted from union leaders and officials actively mobilising in the living areas. Three different types of efforts were evident in three of the eight firms studied: Japan Component had an active Union President who interacted widely in the living areas and organised workshops for workers of all firms, Japan Bike had the only politically affiliated union in the area with a mature and networked union structure and leadership to whom the relatively good working conditions in the firm were attributed, and Korea Auto was a closed firm, albeit with an active union leadership that was establishing links with the state and organised regular gate meetings to inform workers.

In Japan Component, the active Union President interacted widely with workers in their living areas and made efforts to form a political affiliation - an action resisted by management. The dynamism and commitment of the President was evident in his persistent efforts to engage and support workers through personal social interactions, as well as by running workshops in the neighbourhoods to educate all workers about ongoing changes. He was aware of workers' views and fears, summarising them thus:

Workers, quite understandably, want money and want jobs. Have you heard of Korea Good's workers? They cannot even talk out of fear, forget about forming a union. The union would raise issues of excessive workload and misbehaviour but they [workers] will put up with anything because they get higher salaries, gifts and some benefits and they are happy! Look at Japan Auto, the management put an end to their attempts at unionising ... and then harassed those who had tried to do so.

He drew upon examples from the area and from other firms to emphasise his point about developments that affect their lives at three levels: the impact of new economic policies associated with globalisation and anti-globalisation movements, the role of the national government and employers in exploiting workers and curbing union, and the need to form affiliations locally in order to counter employer aggression in the area.

The globalisation that the state propagates is imperialist... in favour of a few, especially the employers. It is restricted to manufacture and trade but not labour ... labour is not free to move.

Employer's strategies are all orientated towards eradicating unions. They have propagated a feeling that unions lead to plant closures and keep bringing up the case of Korea Auto. For them enterprise-based 
unions are ok but collective action through affiliation with other unions and federations is no good. They go all out to oppose it and kill it. They get help from the local 'goons' who intimidate workers, both at work and outside ... And why wouldn't they? They [goons] are the ones who garner lucrative sub-contracts and it is not in either's interest to have strong unions.

While such efforts were appreciated by workers, they were more reticent in expressing the need for political and other affiliations, given their understandable apprehension vis-à-vis potential employer response. Nevertheless, they valued a proximity to the union leader who was welcomed warmly in their homes and social gatherings:

If there is a problem at the workplace in the future, he will be there [Permanent worker, Japan Component].

The President had assumed the role of 'organic' voice by articulating what workers felt, evident in the turnout at one of his workshops (attended by the author). Well aware of workers' dilemmas, the President was nonetheless very positive about the changes in the future:

The increasing differences between the rich and the poor would lead people to rise against the government policies and employers' misbehaviour.

The second case was of Japan Bike. At the other end of the spectrum from the highly individual efforts of Japan Component's Union President, it was one of the oldest and the only firm in the NIZ, with a centrally federated political union, a networked leadership and a workplace with relatively good working conditions. The union representatives in the firm were well rooted in the area and strongly voiced their views during discussions. This stemmed from the better working conditions in the firm, which were widely regarded as an achievement of the union. It had a well-defined union structure with a number of union officials active in the area (unlike Japan Component that relied largely on its President), a hundred percent membership of all the 1,500 employees (core/permanent workers), and an executive of 8-11 members.

\footnotetext{
Japan Bike probably has the best working conditions in the area. Yes ... it is because of their union. Good people. But let us see how long the firm will last [Mixed focus group of workers].
}

In one interview, a union representative made a forceful case for the need and relevance of unions, as well as its political affiliation, by quoting successful cases from his own firm and its other branches in negotiating benefits for all categories of workers.

We are lucky because of our sister organisation in the adjoining state. The central federation was successful in organising workers in that unit. They could show to workers the advantages of having a union. High up people came from the central office and explained things in detail to the workers and whenever there were problems, they would all be there to help us.

Interestingly, at Japan Bike, the longstanding organisation and embedding of the union in the area meant that the enterprise union could see the long-term advantages of being affiliated to a political federation. Asked about employer attitudes to the union's affiliation:

[Laughs] they certainly don't distribute sweets because we are an affiliated union! But they don't have an option. We all know where we would be if the union was not there.

The affiliation allowed the union to draw on a strong network of local and national leaders and representatives who could be called upon in times of crisis or to explain issues to workers. 
Look at the way they are throwing people out all the time. If there is any trouble tomorrow, our leaders will come and stand by us . . they (union leaders) are not opportunistic or with hidden agendas!

Oh, I admit the union leaders can become self-serving but that does not mean unions should not be there or that collective action is not beneficial. The need to be together is even more critical in today's situation.

Relatively better working conditions, successful defence in individual disputes and the maturity of union representatives who displayed an understanding of the realities of workers' lives made Japan Bike a reference point for all workers. At the same time, efforts to mobilise widely were not as strong among Japan Bike's union representatives as in Japan Component and Korea Auto. This was probably because of their strong bargaining position and greater involvement at their own workplace (though they emphasised the need for all workers in the region to unionise).

Korea Auto represented the third and a unique case in the area. Though the firm had been closed for over two years, it had an active union leadership that was establishing links with the state and used the strategy of organised gate meetings to inform former workers about their ongoing campaign. Workers retained a form of affiliation for two reasons. First, there was a sense of injustice at the way the firm closure had been handled. Second, there was a hope that the plant might be reopened or taken over by another firm, or that suitable compensation might be provided. A young former employee active in the union said:

Our union is good ... they have got us this far that we get our salaries and all of us feel it would get us some more things.

Another agreed:

When we were in the firm, we did not value it [union] much. We were getting good salaries; they were among the highest in the region. Who had time for unions? But today we are out and without money ... our union has kept us alive! If it were not for the union we would have no bread in our bellies, be on the road.

The grievances and hopes were reinforced by union leaders during the regular gate meetings at the firm's main entrance. At these meetings, the progress and strategy of the union in its demands from the government were reviewed and discussed.

They hold a monthly meeting of all workers on the premises of the firm, at the gate. They tell us who they have met, what they have been promised by the authorities. Which union would do as much? There is not a single door they have not knocked on ... the district magistrate, the local MP, the central Labour Minister . . . and all of them have promised to help.

This informed as well as served as a unifying factor for former Korea Auto workers while legitimising the role of the union in its interaction with the political and administrative executive.

Union officials from all firms cited the Korea Auto's example as underlining the need for a union (in view of Korea Auto union's visibly active efforts to get justice), along with wider affiliations (that Korea Auto did not have), in order to avoid similar recurrence. Employers, on their part, cited the same case to portend what might happen to unionised or unprofitable firms. More importantly, the struggle and perseverance of Korea Auto's union and sympathy with the very vocal Korea Auto's workers was palpable.

What has been done to them is unfair ... how can a firm just close down and kick so many families in the stomach. We don't know what will happen but their union is good... much better than what unions are like. We hope some deal is worked out for their sake. 
This episode had become a part of the shared collective memory epitomising the hope and despair of workers. It captured the fear they had for their own jobs and a hope that a positive way forward might emerge from the case of Korea Auto.

\footnotetext{
We don't know if the union can succeed . . . not with this kind of government and all the advantage that the employers have. What can happen ... the foreign owners have run away, they can't be brought back? And why will they be ... it is the government that allowed them, maybe helped them to escape? The union is good... but we are not as strong as them... it is difficult. Workers have no one nowadays.
}

It is open to question if the living space focus or community-based mobilisation evident in the above cases can be identified as a nascent form of social movement union or a 'modified' form of enterprise unionism. What is clear is a very vocal expression of workplace specific grievances expressed in alternative spaces, with definite implications for unions.

\section{Implications for enterprise unionism and political mobilisation}

The constraints of the NIZ restricted unionism at the same time as they opened up other spaces for workers' expression, particularly in the living areas, which widened the spatial reach of unions and helped to reshape their strategies. The noticeable tension between political and enterprise unionism provided the context for a shift to broader forms of action: disillusionment, as well as expectations from political unionism, and a pragmatic choice for enterprise unionism accompanied by fear and insecurity at the workplace.

Among many workers across the eight workplaces, as well as in India Chemicals' union, there was a discernible dissatisfaction with political unions and a preference to focus on everyday work and employment issues. This was fiercely opposed by the leadership of the central federation, as well as by unionists at Japan Component, Japan Auto, Japan Bike and Korea Auto. Many workers, particularly those not in the core workforce, were very dismissive of unions:

Oh yes, we know we can make unions and it might do us some good in some ways . . but what is the point? These union people are selfish, thinking about their own benefits and how many jobs they can bargain for their supporters . . . they are of no use to us. We cannot become members or vote because we are not regulars and have no support from anyone ... so we are of no use to them. And look at Japan Bike. They are fully unionised. What good has it done to their contract workers? [Focus group of contract workers]

Most workers (Japan Bike being the exception) expressed a desire for unions that would represent their everyday concerns, not just wider political issues. They appeared willing to accept the change from political unions, and were responding in various ways to enterprise unions, wanting them to be strong and active, not just stooges for employers.

\footnotetext{
Unions like ours are better ... at least they raise issues about us rather than those of the whole world! Take Japan Component, they are affiliated types that you refer to . . . these national ones. Well, two of their Presidents have been murdered . . . Let us see when the third happens. [Sniggers all around] [Focus group of enterprise-based unions' workers].
}

Workers at Japan Component, although supportive of their evidently active Union President, often articulated the futility of expecting any political or state support.

Among the union leadership too there were opposing responses. India Chemical's President was in favour of enterprise unionism. In the remaining three, at Japan Component and Japan Auto, the orientation towards enterprise unionism was more 
by compulsion than choice. Korea Auto had been an enterprise union while it was functioning, but its workers and union leaders felt that an affiliation might have helped them in their present circumstances. Still, an element of pragmatism, not unlike that of the workers, was evident among union representatives:

\footnotetext{
I can understand the new policies, it is happening all over the world. I realise that economic policies imply that firms and multinational companies are inevitable today but the government could control the multinationals like they do in Japan and China ... they dare not do what they do here over there. They are welcome, I am not saying they are not ... but the government should regulate them to create jobs, regularise casuals and give all workers more facilities [Japan Bike union official].
}

These developments may be interpreted alternatively as accommodative unionism associated with the manufacturing sector identified by Fairbrother (2000) in the UK or pragmatism as identified by Edwards (1994). Yet it was accompanied by the desire for a more favourable politico-economic system with stronger labour rights. Workers were well aware of developments in other firms; for example, the Korea Auto union's campaign and negotiations with the state for compensation, as well as the strong politically affiliated unionism at Japan Bike, which was rumoured to be closing down in the near future for the same reason as Korea Auto-excessive unionism and the financial non-viability.

Such mixed reactions reflected workplace reality, but also stemmed from workers' perception of political unionism and its links with the state (all levels) and political parties. Tensions existed between the central union leadership and local union leaders on enterprise unionism. Enterprise unionism and social movement unionism represented similar threats to the central leadership, who emphasised a political engagement for unions. According to a central union federation Secretary:

Cooperative movements or social movements are an effective way of mobilising but when it becomes too big, it is difficult to be honest and transparent. We have used the approach ourselves in our organising drives all over the country to make people and workers and members aware that trade unions can have social relevance beyond just labour. But the problem arises when these movements are presented as an alternative to trade unions ... then it is an agenda because trade unions can become uncomfortable... we question the government, the international changes... we have a broader perspective.

For workers and unions in the area, the tension between different forms of unionism was perceived in a more pragmatic way. Union leaders disagreed on the nature of unionism, with some clearly in favour of enterprise unions (India Chemical's President), while others accepted it out of necessity rather than choice (Japan Component's President). The emergence of the said linkages between work and living spaces was the natural corollary of workplace constraints and a dynamic forged jointly by the workers and their leaders. In this sense, it was a local initiative rather than one encouraged by central federations.

\section{CONCLUSIONS}

The paper has demonstrated the emergence of a new model of unionism: new forms of grass roots community links grounded in the living areas of workers. This represents a significant alternative in the longstanding debate on political versus enterprise unionism, but more so in the constrained context of a NIZ that restricts established forms of unionism. In the context of employer and state pressure-from the global, national, provincial and local level - the terrain of institutionally organised labour 
relations is shrinking: reasonable coverage of enterprise unions, based on good representation and/or bureaucratic structures at the firm level and affiliation to political union federations at the national level, is on the retreat in the current neoliberal climate. However, the same constraints in the NIZ opened up alternative spaces in the living areas for workers' expression, resulting in new forms of labour organisation and strategies. These developments have three significant implications for further research.

First, mobilisation literature (Kelly, 1998; Tilly, 1978) needs to move beyond the workplace to the living areas in order to understand the motivations of workers and strategies of unions in the neoliberal climate. As shown in this paper, the representation of labour's collective interests has been pushed into living areas and wider strategic forms of mobilisation. Given the gross power asymmetries between management and labour, as well as the 'norm' of informal labour, existing social structures outside the workplace offer an important platform for emerging collective (work-based) solidarities (as opposed to work-based collective organisation as such). Thus, the difficulties of enterprise unionism to link into informal work at the same time leave the mobilisation of the overwhelming part of work-based issues to forms of collective organisation that have important roots outside the workplace. Second, while important in organising and channelling labour resistance at the local level, where politically affiliated forms of unions do not reach, it remains to be seen whether grassroots form of union networks can reach beyond the local in challenging neoliberal policies at the national-global level. Lastly, it is the particular interaction of established social structures, different levels of the state and the political economy in the NIZ with global capitalism that provided for varied strategies of workers and unions. The class identity of labour intersected with other identities and persistent links between the workplace and the living spaces of workers impacted upon social interactions, mobilisation and political networking. It is argued that the complexity of such place-specific dynamics necessitates an integrated analysis of the workplace-living areas and workers' experiences in the NIZ within a broader institutional analysis.

\section{References}

Ackers, P. (2002), 'Reframing Employment Relations: The Case For Neopluralism', Industrial Relations Journal, 33, 2-19.

Ackers, P. (2005), 'Theorizing the Employment Relationship: Materialists and Institutionalists' [Book Review], British Journal of Industrial Relations, 43, 3, 537-542.

Bhattacharjee, D. (2001), 'The Evolution of Indian Industrial Relations: A Comparative Perspective', Industrial Relations Journal, 32, 3, 244-263.

Burawoy, M., J. A. Blum, S. George, Z. Gille, T. Gowan, L. Haney, M. Klawiter, S. H. Lopez, S. O. Riain and M. Thayer (2000), Global Ethnography: Forces, Connections and Imaginations in a Postmodern World (Berkeley and Los Angeles, CA and London, University of California Press).

Edwards, P. K. (1994), 'A Comparison of National Regimes of Labor Regulation and the Problem of the Workplace', in J. Belanger, P. K. Edwards and L. Haiven (eds), Workplace Industrial Relations and the Global Challenge (Ithaca, NY, Cornell University Press) pp. 23-42.

Fairbrother, P. (2000), Trade Unions at the Crossroads (London, Mansell).

Gooptu, N. (2001), The Politics of the Urban Poor in Early Twentieth-Century India (Cambridge: Cambridge University Press).

(C) 2010 The Author(s)

Journal compilation (C Blackwell Publishing Ltd. 2010 
Harriss-White, B. and N. Gooptu (2001), 'Mapping India's World of Unorganized Labour', in L. Panitch and C. Leys (eds), Socialist Register 2001: Working Classes, Global Realities (••: Merlin) pp. ••-••.

Hassard, J., L. McCann and J. Morris (2007), 'At the Sharp End of New Organizational Ideologies: Ethnography and the Study of Multinationals', Ethnography, 8, 324.

Hyman, R. (2004), Union Renewal: A View from Europe (London, LSE). [Online]. Research Online. Available from: http://eprints.lse.ac.uk/archive/00000755

Joshi, C. (2003), Lost Worlds: Indian Labour and Its Forgotten Histories (Delhi, Permanent Black).

Kelly, J. (1998), Rethinking Industrial Relations: Mobilisation, Collectivism and Long Waves (London, Routledge).

Kuruvilla, S. and C. L. Erickson (2002), 'Change and Transformation in Asian Industrial Relations', Industrial Relations, 41, 2, 171-227.

Kuruvilla, S., S. Das, K. Hyunji and S. Kwon (2002), 'Trade Union Growth and Decline in Asia', British Journal of Industrial Relations, 40, 3, 431-461.

Mamkoottam, K. (1982), Trade Unionism: Myth and Reality: Unionism in the Tata Iron and Steel Company (Delhi, Oxford, OUP).

Ost, D. (2002), 'The Weakness of Strong Social Movements: Models of Unionism in the East European Context', European Journal of Industrial Relations, 8, 1, 33-51.

Parry, J. P., J. Breman and K. Kapadia (eds) (1999), Worlds of Indian Industrial Labour (New Delhi, Sage Publications).

Ramaswamy, E. A. (1988), Worker Consciousness and Trade Union Responses (New Delhi, OUP).

Ramaswamy, E. A. (1997), A Question of Balance: Labour, Management and Society (Delhi, New York, OUP).

Rose, K. (1992), Where Women Are Leaders: The SEWA Movement in India (London, Zed Books).

Sanyal, B. (1991), 'Organizing the Self-Employed: The Politics of the Urban Informal Sector', International Labour Review, 130, 1, 39-56. Geneva, ILO.

Sanyal, B. (1994), Cooperative Autonomy: The Dialectics of State-NGOs Relationship in Developing Countries (Geneva: International Institute for Labour Studies Research Series $100)$.

Tilly, C. (1978), From Mobilisation to Revolution (Reading, MA; London, Addison-Wesley).

Trivedi, A. (2006), 'Global Factory, Indian Worker', Unpublished PhD thesis, University of London.

Trivedi, A. (2007), 'Global Capitalism, Workers' Spaces and Processes of Selective Inclusion/ Exclusion: Findings from a Newly Industrialising Area in India', Occasional Paper No. 80. Department of HRM, Faculty of Business and Law, De Montfort University.

Venkata Ratnam, C. S. (1998), 'Multinational Companies in India', International Journal of Human Resource Management, 9, 4, 567-589.

Venkata Ratnam, C. S. (2001), Globalisation and Labour-Management Relations: Dynamics of Change (New Delhi, Response Books).

Von Holdt, K. (2002), 'Social Movement Unionism: The Case of South Africa', Work, Employment and Society, 16, 2, 283-304. 


\begin{tabular}{|l|l|}
\hline \multicolumn{2}{|c|}{ Toppan Best-set Premedia Limited, Hong Kong } \\
\hline Journal Code: IRJ & Proofreader: Elsie \\
\hline Article No: 561 & Delivery date: 4 December 2009 \\
\hline Page Extent: 17 & Copyeditor: Dette \\
\hline
\end{tabular}

AUTHOR QUERY FORM

Dear Author,

During the preparation of your manuscript for publication, the questions listed below have arisen. Please attend to these matters and return this form with your proof.

Many thanks for your assistance.

\begin{tabular}{|l|l|l|}
\hline $\begin{array}{c}\text { Query } \\
\text { References }\end{array}$ & Query & Remark \\
\hline q1 & $\begin{array}{l}\text { AUTHOR: A running head short title was not } \\
\text { supplied; please check if this one is suitable and, if } \\
\text { not, please supply a short title that can be used } \\
\text { instead. }\end{array}$ & \\
\hline q2 & $\begin{array}{l}\text { AUTHOR: Please provide the author background } \\
\text { information and corresponding address. }\end{array}$ & \\
\hline q3 & $\begin{array}{l}\text { AUTHOR: Trivedi 2007a has been changed to } \\
\text { Trivedi 2007 so that this citation matches the } \\
\text { Reference List. Please confirm that this is correct. }\end{array}$ & \\
\hline q4 & $\begin{array}{l}\text { AUTHOR: Edwards et al. 1994 has been changed } \\
\text { to Edwards 1994 so that this citation matches the } \\
\text { Reference List. Please confirm that this is correct. }\end{array}$ & \\
\hline q5 & $\begin{array}{l}\text { AUTHOR: Please provide the city location of } \\
\text { publisher and state and page range for this chapter } \\
\text { for Harriss-White and Gooptu 2001. }\end{array}$ & \\
\hline q6 & $\begin{array}{l}\text { AUTHOR: Please check this website address/URL } \\
\text { and confirm that it is correct for Hyman 2004. }\end{array}$ & \\
\hline
\end{tabular}

